\title{
Social Grants Impact on Poverty among the Female-Headed Households in South Africa: A Case Analysis
}

\author{
Job Dubihlela \\ Vaal University of Technology, Vanderbilipark, 1900, South Africa \\ Email: job@vut.ac.za \\ Dorah Dubihlela
}

Faculty of Management Sciences, Vaal University of Technology Private Bag X021, Vanderbijlpark, 1900, Republic of South Africa Email: dorahd@vut.ac.za

\section{Doi:10.5901/mjss.2014.v5n8p160}

\section{Abstract}

\begin{abstract}
The social security system in South Africa plays an important role in mitigating the impact of socio-economic challenges among female-headed households (FHH). Social grants are expanded by the government as a measure of reducing poverty and improving the socio-economic indicators of the poor. South Africa's social grant system is advanced and covers a wide range of vulnerable individuals over their life course from childhood to adulthood; into old age. Policy discourse surrounding the social grants focuses on the sustainability of the system and the implications to livelihood and socio-economic development. It is therefore important that the significance of social grants is shown and particularly highlight their impact on poor FHH. This study investigates the effectiveness of social grants as a safety net among FHH in Bophelong, South Africa. Data was collected from a total of 262 sampled FHH. A significantly larger proportion of FHH qualified for social assistance. Access to the old age pension, child support grant and disability grant remained relatively stable, highlighting the high take-up rate of this grant. Results indicate that social grants play an important role in poverty alleviation among $\mathrm{FHH}$; this translates into a significant reduction of the incidence and severity of poverty in affected households.
\end{abstract}

Keywords: Female-headed households, poverty, social grants, South Africa.

\section{Introduction}

There is a growing need to address extreme poverty, risk and vulnerability particularly when it relates to women. This need has impelled governments to adopt more ambitious goals on poverty alleviation, inequality reduction and women emancipation (World Bank, 2012), for which South Africa has made notable strides since 1994. Poverty is a multidimensional concept capturing a wide range of definitions which may include deficits in income or consumption, deprivations, social exclusions and lack of various capacities (Mbuli, 2008). The policy instruments employed by most governments to reduce poverty include the expansion of a set of instruments broadly classified as social protection (Bhorat \& Kanbur, 2006). Social protection refers to a collection of programs that address risk, vulnerability, inequality and poverty through transfers in cash or kind (Fiszbein, Ringold \& Srinivasan, 2011) and the government social grants are an example. For many countries, expanded social protection programs are important enablers in other key development areas like health, education and also alleviates poverty and hunger (Berhane, Hoddinott, Kumar, \& Taffesse, 2011), especially among the female-headed households (Sekhampu, 2012).

The impact of social protection programs has facilitated their expansion even in low income countries and drawn research attention (Fiszbein \& Schady, 2009). Since 2009, under the threat of the global economic turndown, countries have created new social protection programs, expanded old ones, and improved their administrative systems to make the programs more efficient (Fiszbein et al., 2011). With their aim of redistributing income in favour of the vulnerable groups (Kanbur, 2010), social security directly impacts on both poverty and inequality, serving to reduce both the incidence and the depth of poverty. Other targets include achieving human developmental goals like investment in health, education and nutrition with potential future benefits (Grosh, Ninno, Tesliuc \& Ouerghi, 2008).

The study well acknowledges a body of literature that has highlighted the role of social assistance in South Africa in alleviating poverty (Lekezwe, 2011; Bhorat, Poswell \& Naidoo, 2004; Reddey \& Sokomani, 2008; Makiwane, 2010; Du 
Toit, 2011). Much of the earlier work focused on the success of the old age pension (Case \& Deaton, 1998; Jensen, 2004), the importance of this source of income for household security and household food security (Lund, 1999) and social safety in mitigating chronic poverty if welfare transfers are invested in income-generating activities (Devereux, 2002). These studies have made meaningful contribution to the broad subject. However, a gap has remained on the impact of social grants in reducing poverty among the female-headed households in a Township of a country marked with high inequality like South Africa. This study will therefore attempt to cover this gap. Furthermore, the following scenarios have prompted this study: Poverty is seemingly rising in South Africa yet the expenditure on grants is expanding, both in the amount received by individuals and in absorbing the new poor. FHH have been found to be the major grants recipients yet they continue to be regarded as the poorest households. Then the question that remains is; Are social grants effectively reducing poverty among $\mathrm{FHH}$ ? The remainder of this paper is divided as follows: Section 2 looks at the insight of the South African economy, section 3 covers the methodology of the study, section 4 gives the results and discussion. Section 5 concludes and makes some recommendations and section 7 gives the implications for further studies.

\section{Literature Review}

\subsection{Insight into the South African Economy}

South Africa is regarded as an upper-middle income country yet some of its social indicators are comparable to those of the poorest countries of the world (Bhorat, 2005). Its development profile shows some contradictions with per capita income proportionate with middle-income countries, yet its non-income social indicators lag behind those of comparable countries (Lekezwa, 2011). The apartheid government focused mainly on poverty among Whites, paying little attention to poverty among the Black majority (Seekings, 2007). This skewed approach had limitations, where previous research data was used to promote strategies that reduced White poverty at all costs, often at the expense of Blacks (Wilson \& Ramphele, 1989). Its move into democracy in 1994 brought an urgent concern of overcoming poverty and inequality for all population groups. With enduring structural poverty covering nearly half the population (Lekezwa, 2011), the government comprehended social protection as one of the strategies to alleviate poverty in South Africa. The subsequent section provides a discussion of social security system of South Africa.

\subsection{An overview of South Africa's Social Security System}

The South Africa government has adopted a broadly pro-poor policy framework, which involves an increased share of government expenditure going to social security in the form of social grants (Fiszbein \& Schady, 2009). At present, social grants are administered by the South African Social Security Agency (SASSA), which has made substantial moves to ensure that only legitimate beneficiaries are on the system (Bhorat, Poswell \& Naidoo, 2004). Before democracy, the social security system was fragmented with non-comprehensive coverage (Van der Berg, 1997) where the blacks were marginalised and deliberately excluded from the social security system. The democratic government of 1994 embraced social protection as a way of alleviating poverty and redistributing income through policy and administrative reforms (Lopez, Thomas \& Wang, 2010). The government made moves moves to address the legacy of severe poverty, high unemployment and huge socio-economic inequalities through social security (Swartz, 2004).

Since democracy, SASSA has managed to extend social security to the Black population and addressed the socioeconomic discrepancies and deepened social inclusion of previously marginalised and poor population (Addison, Harper, Prowse and Shepard, 2008). SASSA has further intensified mechanisms to reduce fraud and corruption within the system by starting the reregistration process of grant beneficiaries, on a comprehensive biometric identification system. Contrary, to the above progress, there are some misalignments where the beneficiaries fail to get their grants due to corruption (Reddey \& Sokomani, 2008; Makiwane, 2010). Furthermore, Du Toit (2011) mentions that the coverage remains inadequate calling for the need to further expand social grant expenditure.

Despite a frantic history, social assistance in South Africa is now widely recognised and has transformed as well as increased its access to vulnerable individuals (Reddey \& Sokomani, 2008). Initiatives such as lowering the age requirements for the child support grant and increased public awareness have been carried (Pauw \& Mncube, 2007). The child support grant is the most common and is increasing remarkably. The number of children receiving grant rose from 9.1 million in December 2009 to 10.9 million in 2011/2012 (National treasury, 2012). In 2012/13, SASSA implemented a new payment system that reduced the unit cost per payment from as high as R32 to a standard rate of R16 (Bisseker, 2013). Beneficiaries are able to receive their grants anywhere in the country and have access to the banking system 
(Gordhan, 2013). Generally, social grants in South Africa contribute significantly towards reducing poverty and promoting social development amongst the poor (Samuelson, Macquene. \& Van Niekerk, 2004; Barientos \& Lloyd-Sherlock, 2002).

The seven types of social security grants currently available to South African citizens are the old-age pensions, disability grants, child support grant, care dependency grant, foster child grant, grant-in-aid, and the war veterans' grants. The war veterans' grants is paid to people of 60 years and more, who served in the South African army during the First World War (1914-1918), the Second World War (1939-1945) or the Korean War (1950-1953); and are unable to maintain themselves due to physical and/or mental disability (Lekezwa, 2011). The rise in the number of social security beneficiaries from 2009/10 to the projected 2015/16 is illustrated in Table 1below.

Table 1: Social grants categories \& growth per year

\begin{tabular}{|l|c|c|c|c|c|c|c|c|}
\hline Type of grant/Year & $\begin{array}{c}\mathbf{2 0 0 9 / 1 0} \\
\text { Actual }\end{array}$ & $\begin{array}{c}\mathbf{2 0 1 0 / 1 1} \\
\text { Actual }\end{array}$ & $\begin{array}{c}\mathbf{2 0 1 1 / 1 2} \\
\text { Actual }\end{array}$ & $\begin{array}{c}\mathbf{2 0 1 2 / 1 3} \\
\text { Revised estimate }\end{array}$ & $\begin{array}{c}\mathbf{2 0 1 3 / 1 4} \\
\text { Projected }\end{array}$ & $\begin{array}{c}\mathbf{2 0 1 4 / 1 5} \\
\text { Projected }\end{array}$ & $\begin{array}{c}\mathbf{2 0 1 5 / 1 6} \\
\text { Projected }\end{array}$ & $\begin{array}{c}\text { Average } \\
\text { Annual Growth }\end{array}$ \\
\hline Old age $^{2}$ & 2491 & 2648 & 2711 & 2851 & 2931 & 3013 & 3096 & $3.7 \%$ \\
\hline Disability & 1299 & 1212 & 1172 & 1179 & 1180 & 1181 & 1181 & $-1.6 \%$ \\
\hline Foster care & 489 & 490 & 518 & 529 & 569 & 604 & 633 & $4.4 \%$ \\
\hline Care dependency & 119 & 121 & 122 & 130 & 135 & 140 & 146 & $3.4 \%$ \\
\hline Child support & 9381 & 10154 & 10675 & 11406 & 11699 & 11937 & 12116 & $4.4 \%$ \\
\hline Total & 13779 & 14625 & $\mathbf{1 5 1 9 8}$ & 16095 & 16514 & $\mathbf{1 6 8 7 5}$ & $\mathbf{1 7 1 7 2}$ & $3.7 \%$ \\
\hline
\end{tabular}

1Projected numbers at fiscal year end; ${ }^{2}$ Includes recipients of war veterans grant

Source: National Treasury, 2012

Table 1 shows progress in the recipients of the five common social grants issued in South Africa. The foster care and the child support grants increased the most during the period under review. This development has coincided with global trends towards increased publicly-funded cash transfer to the poor and vulnerable (Smit \& Mpedi, 2010:160) notwithstanding debates, research and advocacy about the effectiveness of these transfers (Barrientos, 2010:18).

The average annual growth in the number of grant recipients was $5.3 \%$ over the four years to $2012 / 13$, and is projected to moderate to $2.2 \%$ a year over the period ahead. For the period ahead, the Department of Social Development has proposed exploring ways to improve income support for orphaned children living with their relatives and phasing out the means test for the old age grant in order to prevent the exclusion of vulnerable individuals. As of the end of the year 2012, the number of beneficiaries by province is shown in table 2 .

Table.2: Social grants recipients by province (31 December 2012).

\begin{tabular}{|c|c|c|c|c|c|c|c|c|}
\hline Region & Old age & War Veterans & Disability & Grant in aid & Care Dependency & Foster care & Child Support & Total \\
\hline EC & 503,810 & 78 & 185,913 & 9,064 & 18,359 & 109,034 & $1,852,147$ & $2,678,405$ \\
\hline FS & 169,336 & 9 & 88,040 & 1,132 & 5,765 & 38,050 & 631,210 & 933,542 \\
\hline GP & 416,222 & 151 & 123,915 & 1,548 & 15,615 & 56,736 & $1,559,585$ & $2,173,772$ \\
\hline KZN & 585,986 & 88 & 319,171 & 28,897 & 35,913 & 132,916 & $2,766,951$ & $3,869,922$ \\
\hline LP & 391,019 & 49 & 88,859 & 10,629 & 11,657 & 53,686 & $1,570,065$ & $2,125,964$ \\
\hline MP & 224,968 & 28 & 82,200 & 2,749 & 8,517 & 33,598 & $1,049,136$ & $1,401,196$ \\
\hline NW & 215,140 & 18 & 87,216 & 3,970 & 8,291 & 39,727 & 746,299 & $1,100,661$ \\
\hline NC & 74,023 & 18 & 49,795 & 4,203 & 4,445 & 13,408 & 274,073 & 419,965 \\
\hline WC & 258,117 & 167 & 154,954 & 9,437 & 10,654 & 27,738 & 854,473 & $1,315,540$ \\
\hline Total & $\mathbf{2 , 8 3 8 , 6 2 1}$ & $\mathbf{6 0 6}$ & $\mathbf{1 , 1 8 0 , 0 6 3}$ & $\mathbf{7 1 , 6 2 9}$ & $\mathbf{1 1 9 , 2 1 6}$ & $\mathbf{5 0 4 , 8 9 3}$ & $\mathbf{1 1 , 3 0 3 , 9 3 9}$ & $\mathbf{1 6 , 0 1 8 , 9 6 7}$ \\
\hline
\end{tabular}

Source: SASSA, 2012:1

The province with the largest number of grant recipients was Kwa-Zulu Natal followed by the Eastern Cape Province while the Northern Cape had the least recipients. The most common was the child grant with 11303939 children receiving it. The war veterans' grant had the least number of people. 


\section{Methodology}

\subsection{Data Collection}

The results discussed in this paper are based on cross-sectional data collected through in-house personal interviews by means of questionnaires in a Township of Bophelong in the Gauteng province of South Africa. Townships in South Africa are underdeveloped urban areas that, from the late 19th century until the end of Apartheid, were reserved for non-Whites, thus Blacks, Coloureds and Indians. Like any other Townships in South Africa, Bophelong houses mainly Black residents with $99.12 \%$ of the population being Black (Census, 2011). The average household size in Bophelong, calculated from Statistics SA (2007), is 3 persons per household. A pilot study was conducted on a sample of 25 respondents. This was done in order to test validity, reliability and applicability of the research instrument; also to ensure that the questionnaire meets the researcher's expectations in terms of the information obtained (Aaker, Fourner, \& Brasel, 2004). Necessary adjustments were made on the questionnaire after which a total of 316 household questionnaires were administered and 172 were found to be headed by women. The second survey was done on 60 female-headed households making a total sample size of 262 households and capturing information for 951 household members. Census (2011) found a total number of 14257 households in Bophelong. This sample was considered representative and was in line with a survey by Slabbert (2009) who had a sample size of 286 households. The questionnaire was adapted from Slabbert (2009) and edited to fit the research focus and then administered by the principal authors with the assistance of four trained interviewers.

\subsection{Poverty Measurement}

\subsubsection{Poverty line calculation}

Income poverty line was used where the poor households were those who were below their household poverty line. The study uses the monthly calorie intake of 2261 kilocalories per individual per month as recommended by the African Medical Research Council (SAMRC) (Bhorat \& Westhuizen, 2010). Using year 2000 Income and Expenditure Survey data, Stats SA estimated that it costs R211 per capita per month to satisfy a daily energy requirement of 2261 kilocalories. A further consideration was made for other goods and services beyond food by individuals which includes accommodation, energy, clothing, transport and medical services, amongst other things. SAMRC estimates such essential non-food items to be R111 per capita per month, giving a total of R322 per person per month in 2000 prices. Hoogeveen and Özler (2004) noted the same poverty line of R322 as a lower poverty line, further proposing an upper poverty line of R593 per capita per month using the year 2000 prices. These two poverty lines were later supported by other researchers (Mabugu \& Chitiga, 2007; Stats SA, 2007). This study adopted this lower poverty line (R322 per capita per month using 2000 prices). When increased with inflation, the lower threshold amounted to R570 in 2010 (Stats SA, 2011). For this study the lower poverty line was adjusted for inflation up to March 2012 and calculated at R584 per capita per month.

\subsubsection{Poverty incidence}

Poverty incidence was measured using head-count index which measures the number of poor households falling below the poverty line. The following formula was used according to Makoka and Kaplam (2005):

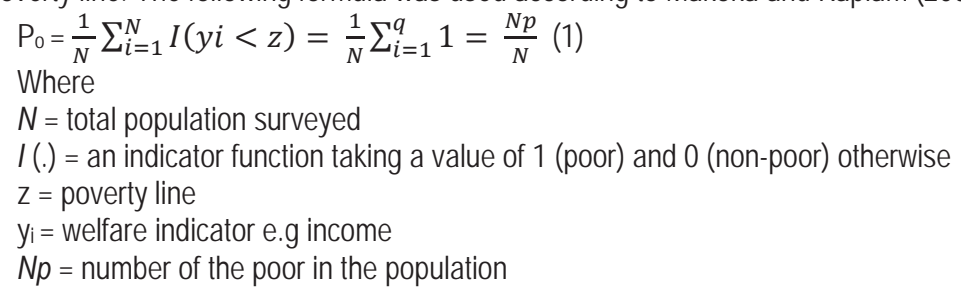

\subsubsection{Poverty Intensity-depth of poverty}

Poverty intensity was measured using poverty gap and the poverty gap index. Poverty gap measures the average deficit 
in the income of the poor in relation to their poverty line, whereas the poverty gap index measures the extent of the deficit of income below the poverty line. The poverty gap for an individual household was measured by the formula according to (Oldewage-Theron \& Slabbert, 2010):

$\mathrm{Gi}(\mathrm{y} ; \mathrm{z})=\mathrm{zi}-\mathrm{yi}(2)$

Where: $\mathrm{Gi}=$ the income shortfall of a household

yi $=$ the income of a specific household

$z i=$ the poverty line of a specific household.

The poverty gap index of a specific household was calculated by the following equation (Oldewage-Theron \& Slabbert, 2010):

$$
\operatorname{Ri}(y ; z)=\frac{Z i-Y i}{Z i}(3)
$$

Where: $\mathrm{Ri}=$ the income shortfall of a household, which is expressed as a proportion of the household's poverty line $Y i=$ the income of a specific household

$Z i=$ the poverty line of a specific household.

\section{Results and Discussion}

\subsection{Descriptive Statistics}

The results of the survey are shown below.

Table 3: Descriptive Statistics

\begin{tabular}{|l|c|c|l|c|c|c|c|c|}
\hline Marital Status & $\mathbf{N}$ & $\%$ & Grants received & $\mathbf{N}$ & $\%$ & Ages of the recipients & N & $\%$ \\
\hline Married & 9 & 3 & Child grant & 158 & 60 & $0-15$ & 149 & 57 \\
\hline Divorced & 87 & 33 & Old age Pension & 87 & 33 & $16-30$ & 20 & 8 \\
\hline Widowed & 60 & 23 & Foster care & 7 & 3 & $31-45$ & 0 & 0 \\
\hline Separated & 12 & 5 & Care dependency & 5 & 2 & $46-60$ & 4 & 1 \\
\hline Never married & 94 & 36 & Disability & 5 & 2 & $60+$ & 89 & 34 \\
\hline Total & $\mathbf{2 6 2}$ & $\mathbf{1 0 0}$ & & $\mathbf{2 6 2}$ & $\mathbf{1 0 0}$ & & $\mathbf{2 6 2}$ & 100 \\
\hline
\end{tabular}

$\mathrm{N}$ in the marital status represents the number of households heads while in the grants received and in the ages of the recipients it represents the total number of household members. In the table, only $3 \%$ of the household heads were married, indicating that these were de facto female-headed households, thus heading households where there is a husband in existence. The never married households were $36 \%$ while the divorced, widowed and separated were $33 \%$, $23 \%$ and $5 \%$ respectively. The most common grant was the child grant where $60 \%$ of the grant recipients received it followed by the old age pension with $33 \%$ of grants recipients were receiving it. The largest age group which received social assistance (57\%) was the population aged 15 years and below, who were the child grant recipients, followed by $60+$ who mainly were the recipients of the old age pension with $34 \%$ of the recipients. The recipient of the foster care grant was the foster parent not the child. No social assistance was received by the population aged 31-45 years in the sample.

\subsection{Impact of Grants on Poverty}

Poverty incidence, using income inclusive of grants among the female-headed households was $75.12 \%$. The poverty gap R1684 (about USD153) was and the poverty gap index was 0.582 indicating that on average, poor households had a $58.2 \%$ deficit in income in respect of maintaining a level of income that would be equal to their respective poverty lines (Oldewage-Theron \& Slabbert 2008:95).

Given that a relatively significant proportion of the income of $\mathrm{FHH}$ is made up of social grants, it is likely that social grants play an important role in alleviating poverty in these households. Social grants impact was accessed by way of calculating the standard poverty measures both inclusive and exclusive of grants. This allows one to assess the impact of social grants on the incidence (head-count) and the depth (poverty gap) of poverty. These results are reported in Table 4. 
Table 4: Grants impact on poverty

\begin{tabular}{l|c|c|c}
\hline Income & Headcount index (\%) & Poverty gap in R & Poverty gap index (\%) \\
\hline Income without child grant & 77.95 & 1801 & 62.8 \\
\hline Income without old age pension & 81.24 & 1931 & 68.3 \\
\hline Income without other grants & 77.21 & 1748 & 60.5 \\
\hline Income without any grant & 86 & 2092 & 75.2 \\
\hline
\end{tabular}

Social grants played an important role in alleviating poverty in the FHH. In percentage terms, the incidence and the depth of poverty dropped as a result of social assistance. The reduction in the incidence and depth of poverty (i.e. the percentage change in the poverty measure calculated at baseline exclusive of social grants, and the poverty measure calculated at baseline inclusive of social grants) was more significant. The incidence of poverty increased by $10.1 \%$ and the depth of poverty rose by $17 \%$ as a result of the removal of social grants from households' income. Removing the old age pension from the households' income increases poverty rate and the poverty gap index the most $(6.04 \%$ increase in poverty rate and $10.1 \%$ increase in poverty gap index). Removing the child grant increases poverty head count by $2.75 \%$ and poverty gap by $4.6 \%$ while removing other grants (foster care grant, care dependency grant, disability, grant in aid and the war veteran's grants) increases poverty by $2.01 \%$ and the poverty gap index by $2.3 \%$. In money terms, the poverty gap increases by R247 if old age pension is removed, by R117 if the child grant is removed and by R64 if other grants are removed.

\section{Conclusion and Recommendations}

This study focused on the poverty reduction effect of government social security system among the FHH in a South African Township using three criteria, poverty incidence and poverty gap and the poverty gap index. Incomes from grants served to reduce both the poverty incidence and the poverty intensity. The empirical evidence indicates that social security helps households escape from poverty and further reduce the poverty gap and the poverty gap index. Social grants bring very poor people closer to the poverty line and lift some out people out of poverty. The effect in poverty reduction however differs with a type of assistance. The old age pension was the most the effective grant in reducing both the poverty incidence and the poverty intensity, though received by few individuals compared to the child grant. This is due to the value difference between these grants where the child grant was R270 per recipient per month while the old age pension was R1440 per recipient per month during the time of the survey. The other grants were the least in poverty reduction because they were received by few individuals.

The persistence of poverty among $\mathrm{FHH}$ yet social security spending by the government is rising can be caused by a rise in poverty which is more than the government policies on social spending can cope. Social security is however not the only weapon used to fight poverty; others like employment creation are used as well. An increase in the number of $\mathrm{FHH}$ due to loss of the male provider can be a possible cause of high poverty reported in these households. Therefore, though $\mathrm{FHH}$ are the major recipients of grants, poverty in these households persists.

The following recommendations are made emanating from the study results. In order to effectively reduce poverty in the township, the income threshold used in the means test for affordability should be decreased since households that meet the current means test criteria are already poor, and can always fall into extremely poor, with a slight price rise. Lowering the age limit for the old age pension will increase the number of individuals qualifying and hence reduce poverty. Furthermore, the South African government should consider increasing the absolute size of the child grant since households complained that it was insufficient to carter for the child's needs and also move in with speed in absorbing the new vulnerable individuals into the safety nets.

This paper recommends the retention of grants as an important form of anti-poverty strategy among $\mathrm{FHH}$. The sheer magnitude of poverty in South African townships also requires one to consider the fiscal affordability and sustainability of the social protection system in the future. Findings reported in this paper have proven that grants are worthwhile policy instruments, although they are not the ultimate solution.

\section{Implications for Future Research}

Even though there is a wide body of literature in social protection and poverty, which have identified poverty among female-headed households, the existing literature is full with empirical evidence pointing out great poverty incidence among female-headed households. The current study was set to depart from these long held attempts to find the effect of 
social grants on poverty but investigate this effect among the FHH in a Township set up. Although this study makes significant contributions to both academia and policy-making, it remains limited in some ways, and therefore some future research paths are suggested. First, the data used was cross sectional gathered from a township in the Gauteng Province of South Africa. The results would be more informative if pane data was gathered to note the trends overtime. Secondly, future studies should not be limited to South Africa, but rather consider extending to other African countries such as Lesotho for results comparison and also consider comparing the social grants impact with that of male-headed households. Above and beyond, this will immensely contribute new knowledge to the existing body of the subject of poverty in the African setting. The paper further suggests the need for continued research on the causal relationship between poverty and the social grants. The study also suggests expanding the sample size in order to capture a wide range of grants and their significance in poverty reduction.

\section{References}

Aaker, A., Fourner, S. \& Brasel, S.A. (2004) When good brand do bad. Journal of Consumer Research, Vol 31, pp 1-17.

Addison, T., Harper, C., Prowse, M., Shepherd, A. and other co-authors. (2008) The Chronic Poverty Report 2008-09. Manchester: Chronic Poverty Research Centre, Brooks World Poverty Institute.

Barrett, C.B. \& Carter, M.R. (2012) The economics of Poverty traps and persistent poverty: Policy and empirical applications: Cornell University.

Barrientos, A. (2010) Poverty reduction and policy regimes. Washington D.C.: United Nations.

Barrientos, A. \& Lloyd-Sherlock, P. (2002) Health insurance reforms in Latin America: Cream skimming, equity and cost containment, in L. Haagh and C. T. Helgo (eds), Social Policy Reform and Market Governance in Latin America, London: Palgrave

Berhane, G., Hoddinott, J., Kumar, N. \& Taffesse, A. S. (2011) The Impact of Ethiopia's Productive Safety Nets and Household Asset Building Programme: 2006-2010. Addis Ababa: International Food Policy Research Institute.

Bhorat, H. (2005) Labour Supply and Demand Constraints on Employment Creation: A Microeconomic Analysis. Paper Presented to School of Development Studies 50th Anniversary Conference. University of KwaZulu-Natal: Durban.

Bhorat, H, \& Kanbur, R. (2006) Poverty and Policy in Post-Apartheid South Africa. Pretoria: HSRC Press.

Bhorat, H., Poswell, L. \& Naidoo, P. (2004) Dimensions of Poverty in post-Apartheid South Africa. Development Policy Research Unit. Rondebosch: University of Cape Town.

Bhorat, H. \& Westhuizen, C. (2010) Estimating a poverty line: An application to free Basic and Municipal Services in South Africa. Rondebosch: Development Policy Research Unit.

Bisseker, C. (2013) South Africa's welfare net keeps social stability. Johannesburg: Financial mail.

Census South Africa. (2011). Census. Web: http://census2011.adrianfrith.com/place/760013. Date of access: 3 Feb 2014.

Devereux, S. (2002) Social Protection for the Poor: Lessons from Recent International Experience. IDS, Working Paper No.142, Brighton.

Du Toit, D.C. (2011) Food Security. Directorate Economic Services Production Economics unit. Department of Agriculture, Forestry and Fisheries, South Africa. Web: http://www.daff.gov.za/docs/GenReports/FoodSecurity.pdf Accessed on 01 August 2013.

Duflo, E. (2000) Grandmothers and Granddaughters: Old Age Pension and Intra-household Allocation in South Africa. National Bureau of Economic Research Working Paper No. 8061.

Fiszbein, A. \& Schady, N. (2009) Conditional Cash Transfers: Reducing Present and Future Poverty. Washington, DC: World Bank.

Fiszbein, A., Ringold, D \& Srinivasan, S. (2011) Addressing children's vulnerability to economic shocks through cash transfers, in Development Policy Review, 29 (5) pp, 585-602

Gordhan, P. (2013) Budget Speech. Pretoria: National Treasury.

Grosh, M., Ninno, C., Tesliuc, E. \& Ouerghi, A. (2008) For protection \& promotion: The design and implementation of effective safety nets. Washington, D.C.: The World Bank.

Hanlon, J., Barrientos, A. \&Hume, D. (2010) Just Give Money to the Poor: The Development Revolution from the Global South. Sterling: Kumarian Press.

Hagen-Zanker, J., Morgan, J and Meth, C. (2011) South Africa's cash social security grants: Progress in increasing coverage. London: ODI Publications.

Hoogeveen, J. G. \& Özler, B. (2004) Not separate, not equal: Poverty and inequality in post apartheid South Africa. Washington D.C.: World Bank.

Kanbur, R. (2010) Conceptualising social security and income redistribution. Web: www.kanbur.aem.cornell.edu. Date of access: 4 Dec. 2013.

Lekezwa, B.I. (2011) The Impact of Social Grants as Anti-Poverty Policy Instruments in South Africa: an Analysis Using Household Theory to Determine Intra-Household Allocation of Unearned Income. Mcom Dessertation: University of Stellenbosch

Lopez, R.E. Thomas, V. \& Wang,Y. (2010) The effect of fiscal policies on the quality of growth. Washington D.C.: World Bank.

Lund, F. (1999) Understanding South African social security through recent household surveys: new opportunities and continuing gaps. Development Southern Africa, 16(1), pp 55-69.

Mabugu, R. \& Chitiga, M. (2007) Poverty and inequality impacts on trade policy reforms in South Africa. Pretoria: University of Pretoria.

Makinana, A. (2012) Social grants: 15.3 million people to register again. Web http://mg.co.za/article/2012-02-15-social-grants-153million- 
people-to-register-again. Date of access: 13 Jul 2013.

Makiwane, M. (2010) The child support grant and teenage childbearing in South Africa. Development Southern Africa. 27(3), pp 193204.

Makoka, D. \& Kaplan, M. (2005) Poverty and vulnerability. Bonn: University of Bonn.

Mbuli, B.N. (2008) Poverty reduction strategies in South Africa. Pretoria. Mcom dissertation: UNISA

National Treasury. (2012) Budget review. Pretoria: Department of Finance

National Treasury. (2012) Social security and the social wage. Pretoria: National Treasury

NSPCC. (2008) Poverty and child maltreatment: Child protection research briefing.

Oldewage-Theron, W.H. \& Slabbert, T.J.C. (2008) Impact of food and nutrition interventions on poverty in an informal settlement in the Vaal Region of South Africa. Proceedings of the Nutrition Society 67, 91-97.

Oldewage-Theron, W. \& Slabbert, T.J.C. (2010) Depth of poverty in an informal settlement in the Vaal region, South Africa. Health SA Gesondheid 15(1), Art. \#456, 6 pages. DOI: 10.4102/hsag.v15i1.456.

Øyen, E. (2005) The polyscopic landscape of poverty research. Norway: Research council of Norway.

Pauw, K. \& Mncube, L. (2007) Expanding the social security net in South Africa: Opportunities, challenges and constraints. Washington D.C: United Nations Development Programme:

Reddy, T. \& Sokomani, A. (2008) Corruption and Social grants in South Africa. Rondebosch: Department of Social Development.

Samuelson, M., Macquene, K. \& Van Niekerk, I. (2006) Inter-regional inequality facility: Sharing ideas and policies across Africa, Asia and Latin America. Claremont: Economic Policy Research.

SASSA. (2012) Fact Sheet No 4 of 2012. Summary of social grants distribution in South Africa as at April 2012. http://www.sassa.gov.za/Portals/1/Documents/815477a6-9e37-4590-a785-7b934f045e52.pdf Date of access 4August 2013

Seekings, J. (2007) Poverty and Inequality after apartheid. Paper prepared for the second 'After Apartheid Conference', Yale, 27-28 April 20072

Sekhampu, T.J. (2012) Socio-economic determinants of poverty amongst female-headed households in a South African Township. International Journal of Social Sciences and Humanity Studies, 1 (4), pp 409-418.

Slabbert, T.J.C. (1997) Poverty amongst black households in the Vaal Triangle Metropolitan Area: a micro-analysis. Vanderbijlpark: Vista University. Thesis -PhD

Slabbert, T.J.C. (2009) Unpublished results of Bophelong household survey. Vanderbjjlpark: Vaal Research Group.

Smit, N. \& Mpedi, L.G. (2010) Social protection for developing countries: Can social insurance be more relevant for those working in informal economy? Law Democracy and development, (4), pp 159-187.

Statistics South Africa (Stats SA). (2011) Social profile of vulnerable groups in South Africa 2002 - 2010. Pretoria: Government Printer.

Statistics South Africa (Stats SA). (2007) A national poverty line for South Africa. Pretoria: Government Printers.

Statistics South Africa (Stats SA). (2005) Income and Expenditure Survey (IES). Pretoria: Government Printers.

Swartz, L. (2004) Overview of poverty situation and reduction in South Africa over the past 10 years. Pretoria: Department of Social Development.

Van der Berg, S. (1997) South African social security under apartheid and beyond. Development South Africa. 14 (4), pp 481-503.

Westhuizen, C. V. D. (2012) South Africa: Economic growth, poverty and inequality. Rondebosch: Development Policy Unit.

Wilson, F. \& Ramphele, M. (1989) Uprooting poverty: The South African challenge. Rondebosch: Danci Phillip Publishers.

World Bank. (2012) Resilience, Equity and Opportunity. Social Protection and Labor Strategy.Washington DC.: World Bank. 